\title{
The Role of Judges Based on Considerations of Community Cultural Values to Create Justice
}

\author{
Handika Naufal Husni*), Widayati**) \\ ${ }^{*}$ Student of Master of Law, Faculty of Law, Universitas Islam Sultan Agung \\ Semarang, E-mail: handikanaufalhusni@gmail.com \\ ${ }^{* *}$ Lecturer of Master of Law, Faculty of Law, Universitas Islam Sultan Agung \\ Semarang
}

\begin{abstract}
.
This paper discusses the role of judges based on the cultural values of the community in realizing justice. With the sociological juridical approach method, namely through the role of judges in court to realize justice. In realizing justice, judges apply the law based on a verdict and the judicial power law that judges have rights and a code of ethics which is specifically regulated in law. Regarding the culture of the community that still exists, it is hoped that the role of the judge is to actualize justice by putting in place a rule and implementing a decision with a legal background that exists in the community, namely customary law as an addition to a decision.

Keywords: Role of Judges; Legal Culture; Justice.
\end{abstract}

\section{Introduction}

The concept of a rule of law is basically an embodiment of the principle of people's sovereignty or democracy. ${ }^{1}$ The concept of rechsstaat was born after the growing understanding of a sovereign state and the development of treaty theory regarding the formation of a state initiated by JJ Rousseau. Dicey, F. Julius Stahl stated that there are four important elements of a rule of law, namely:

- Protection of human rights

- Division or separation of powers to guarantee human rights.

- Government based on law.

- State administrative court. ${ }^{2}$

The characteristics of a rule of law as well as a rule of law with the concept of rechtsstaat are as follows:

- A country whose life is in line with the constitution and laws the process of making is carried out by the parliament.

- The state regulates the accountability mechanism for every policy and action taken by the state elite.

- The state guarantees the independence of judicial power.

\footnotetext{
1 Fitriciadi, Aidul. (2005). Kekuasaan Kehakiman Yang Merdeka Dan BertanggungJawab di Mahkamah Konstitusi: Upaya Menemukan Keseimbangan. Surakarta: Jurnal Jurisprudence Volume 2 No. 1. p. 94.

2 Safaat, Ali. (2016). Modul Pendidikan Negara Hukum Dan Demokrasi. Jakarta: Pusat Pendidikan Pancasila Dan Konstitusi Mahkamah Konstitusi. p. 12.
} 
- A country that protects human rights. ${ }^{3}$

Indonesia is a state based on law as referred to in Article 1 paragraph (3) of the 1945 Constitution, ${ }^{4}$ contains the understanding that all life orders of the nation, society and state are based on law. ${ }^{5}$

Sociologically, justice that is tried to be formulated in statutory regulations is of course limited to justice that is understood and felt by the legislators, and is also limited to when the statutory regulations were formed. On the other hand, the sense of justice in society always develops along with the development of the conditions of the society itself. Justice is the spirit or soul of statutory regulations. ${ }^{6}$

Based on their authority and duties as the main actor of the court's function, the judge's attitude symbolized in kartika, chakra, candra, sari and tirta is a reflection of the judge's behavior which must always be implemented and realized by all judges in the attitude and behavior of judges based on the principle of a divine The One and Only, just, wise and dignified, virtuous, and honest. Faith in God Almighty, which underlies the principles of the code of ethics and the code of conduct for judges means the practice of behavior according to each religion and belief according to the basisjust and civilized humanity. This devotion to God Almighty will be able to encourage judges to behave well and be full of responsibility in accordance with the teachings and guidance of religion and belief.7 $^{7}$

The Constitution of the Republic of Indonesia Number 48 of 2009 concerning judicial power article 1 :

- Judicial power is the power of an independent state to administer the judiciary to uphold law and justice based on Pancasila and the 1945 Constitution of the Republic of Indonesia, for the sake of the implementation of the State of Law of the Republic of Indonesia.

- The Supreme Court is an actor of judicial power as referred to in the 1945 Constitution of the Republic of Indonesia.

- The Constitutional Court is the actor of judicial power as referred to in the 1945 Constitution of the Republic of Indonesia.

- The Judicial Commission is a state institution as referred to in the 1945 Constitution of the Republic of Indonesia.

- Judges are judges at the Supreme Court and judges in the judiciary under it in the general court, religious courts, military courts, state administrative courts, and judges at special courts within the said court.

- Supreme Judge is a judge at the Supreme Court.

- Constitutional Justices are judges at the Constitutional Court.

\footnotetext{
3 Simamora, Janpatar. (2014). Tafsir Makna Negara Hukum Dalam Perspektif Undang-Undang Dasar Negara Republik Indonesia Tahun 1945. Medan: Jurnal Dinamika Hukum Volume 14 No. 3. p. 555.

${ }^{4}$ Article 1 paragraph (3) of the 1945 Constitution of the Republic of Indonesia.

5 The 1945 Constitution of the Republic of Indonesia, Fourth Amendment. p. 96.

6 Widayati. (2020). Implementasi Asas Hukum Dalam Pembentukan Peraturan Perundang-Undangan Yang Partisipatif Dan Berkeadilan. Semarang: Jurnal Hukum Volume 36 No.2 Unissula. p. 70.

${ }^{7}$ Mardani. (2017). Etika dan Profesi Hukum. Depok: Rajawali Pers. p. 185.
} 
- Special Court is a court which has the authority to examine, try and decide certain cases which can only be established in one of the jurisdictions of a judicial body that is under the Supreme Court as regulated by law.

- Ad hoc judges are judges of a temporary nature who have expertise and experience in certain fields to examine, hear and decide a case whose appointment is regulated by law. ${ }^{8}$

As explained above, it is based on the mission of the judicial power function as stated in Article 24 paragraph (1) judicial power is an independent power to administer the judiciary to uphold law and justice, Article 28 D paragraph (1) everyone has the right to recognition, guarantee, protection, and legal certainty that is just and equal treatment before the law. ${ }^{9}$ Free from interference from parties outside the power of the judiciary to administer justice for the sake of implementing a rule of law. ${ }^{10}$

This study aims to determine the role of judges in adjudicating cases based on considerations of the cultural values of society to achieve justice and to find out the analysis of judges in adjudicating cases based on considerations of the cultural values of society to achieve justice.

\section{Research methods}

The approach method used in this study is a sociological juridical approach. Sociological juridical approach is to identify and conceptualize law as real and functional social institutions in real life systems. ${ }^{11}$

\section{Results and Discussion}

\subsection{The Role of Judges in Adjudicating Cases Based on Considerations of Community Cultural Values to Achieve Justice}

In principle, the court is passive and only waits for every case submitted to it, or in other words, judges as law enforcers are prohibited from requesting or suggesting a dispute or problem, both criminal and civil, to be resolved in court. Although the court is passive in waiting for a case, when the case has been submitted or delegated to it and becomes its authority, the court is prohibited from rejecting the case on the grounds that the law does not exist or is unclear because the judge is always considered to know the law.

Every case submitted to the court must continue to be tried, regardless after being tried and the judge declares that the case is not a criminal act or is not within the scope of his competence, the court must continue to adjudicate, regardless after being tried then the judge declares that the case is not a criminal act or not

\footnotetext{
8 The Constitution of the Republic of Indonesia Number 48 of 2009 concerning Judicial Powers.

${ }_{9}^{9}$ Muslih, M. (2013). Negara Hukum Indonesia Dalam Perspektif Teori Hukum Gustav Radbruch (Tiga Nilai Dasar Hukum). Jambi: Legalitas Edisi Volume IV Nomor 1. p. 138.

10 Zaidah, Yusna. (2015). Religious Courts in Indonesia. Banjarmasin. p. 33.

11 Soekanto, Soerjono. (2006). Pengantar Penelitian Hukum. Jakarta: Universitas Indonesia Press. p. 51.
} 
within the scope of its competence, the court must declare it in the form of a decision not in the form of a case rejection before being tried.

Justice seekers certainly desire that cases submitted to court can be decided by judges who are professional and have high moral integrity so that they can create decisions that not only contain legal justice but can also include moral justice and social justice. In the event that the handling of cases in court and the law is incomplete or unclear, there is a legal vacuum in a case that is submitted to the court, it is the judge's duty to explore and find laws that can be used to settle the cases he faces in order to adapt to the demands of community development.

Legal discovery is a process of legal formation by the subject or actor of legal discovery in an effort to apply general legal rules to events based on certain principles or methods that can be justified in legal science, such as interpretation, reasoning, exposition (legal construction) and others. . These principles or methods are used so that the application of legal rules to the event can be carried out appropriately and according to law, so that the results obtained from the process can also be accepted and accounted for in the science of law. Thus, judges must have the ability and creativity to be able to resolve and decide cases by seeking and finding law in cases where there is no legal regulation.

This makes it easier for judges to settle cases because they not only convey the sound of the law but can make legal discoveries from various sources of legal discovery and can also create laws because the law actually exists in society. Where there is a community there is of course there is law, it remains how we explore so that law enforcement can truly fulfill the sense of justice in society. If you make legal discoveries based on the value of justice in deciding cases and then the judge's decision becomes law, a law will be created that is truly in accordance with the values of justice that exist in society. ${ }^{12}$

The Bangalore Principles lists six important principles that must be used as guidance for judges in the world, namely the principles:

- Independence (Independence Principle).

- Impartiality (Impartiality Principle).

- Integrity (Integrity Principle).

- Appropriateness and politeness (Propriety Principle).

- Equality (Equality Principle).

- Competence and Diligence Principle.

The six principles of judge ethics make Indonesian judges formulate their own code of ethics that applies in Indonesia. In this connection, the Constitutional Court has established a code of ethics for constitutional judges as stipulated in the constitutional court regulation No. 07 / PMK / 2005. So it can be stated that the judiciary in Indonesia is the supreme court and the judiciary under it, the

\footnotetext{
12 Annisa, Nur Fitra. (2017). Peranan Hakim Sebagai Penegak Hukum Berdasarkan Undang-Undang Nomor 48 Tahun 2009 Tentang Kekuasaan Kehakiman, Jurnal Lex Et Societatis Volume. 5 No. 3. p. 161.
} 
constitutional court, and the judicial commission as proposers, appointments and guardians of honor for judge behavior. ${ }^{13}$

\subsection{Analysis of Judges in Adjudicating Cases Based on Considerations of Community Cultural Values to Achieve Justice}

In a broader understanding, Lawrence M. Friedman includes a legal culture component as an integral part of a legal system. Friedman distinguishes the elements of the legal system into 3 (three) types, namely: (1) structure; (2) substance; and (3) culture. The "structure" component is an institution created by the legal system with various functions in supporting the operation of the legal system. The "substance" component is the output of the legal system, including norms which, among others, are in the form of statutory regulations. All of that is used to regulate human behavior. Meanwhile, "culture" (culture) are the values and attitudes which bind the system and determine the place of the system in the midst of the nation's culture as a whole. On this point Friedman asserts. ${ }^{14}$

Each law is a system, that is, the rules are unanimity based on the unity of the mind, as well as customary law. Therefore, Indonesian customary law is an aspect of the life and culture of the Indonesian people which is the essence of the necessities of life, way of life and outlook of life of the Indonesian people or nation.

So the Indonesian customary law system will be based on the basics of the mind of the Indonesian people which of course will not be the same as the mindset and outlook of life of other nations or communities, especially nations or communities in the western hemisphere (Europe). In order to get deeper into and better understand the customary law system, people must explore the basic thoughts that live in Indonesian society. ${ }^{15}$

Basically, law is not just a black and white formula as stated in various forms of legislation, but law should be seen as a phenomenon that can be observed in people's lives through the behavior patterns of its citizens. This means that law is strongly influenced by non-legal factors such as: values, attitudes and views of society which are commonly referred to as legal culture / culture. The existence of this legal culture / culture causes differences in law enforcement between one society and another.

If we look at the reality in Indonesia, especially in rural areas, it is clear that the values contained in the law are different from the values inherent in the life of rural communities. This is because the level of knowledge of the village community is still low, so they find it difficult to understand what the law requires. In dealing with conditions like this, there are several things that need to be considered, namely: the role of the implementing bureaucracy, namely the village head, is very important in making the law effective in society, the need for well-executed legal communication so that people understand the existing law, the means of conveying

${ }^{13}$ Usman Rasyid dkk. (2020). Wajah Kekuasaan Kehakiman Indonesia. Yogyakarta: UII Press. p. 19.

${ }^{14}$ Warassih, Esmi. (2016). Pranata Hukum Sebuah Telaah Sosiologis. Semarang: Pustaka Magister. p. 81.

${ }^{15}$ Nugroho, Sigit Sapto. (2016). Pengantar Hukum Adat Indonesia. Solo: Pustaka Iltizam. p. 61. 
the contents of a regulation the law must be sufficient for the public to participate in the legal mobilization process. Other than that, The effectiveness of the law can also be achieved by instilling new values through the institutionalization process so that it can become a new pattern of behavior in the framework of forming public legal awareness. It can be understood that efforts to instill a new legal culture can be achieved if the institutionalization process has been carried out properly and seriously for the creation of public legal awareness.

There are 5 (five) types of judicial order that apply, namely:

- The gubernemen judicial order (gouvermen rechts praak) which covered the entire territory of the Dutch East Indies which consisted of various types of justice.

- Indigenous judiciary (inheemsche rechts praak) existing in regions that have the freedom to conduct their own judiciary with indigenous judges.

- The self-governing judiciary (zelbestuur strechts praak) located in the selfgoverning regions.

- religious courts (raad religion) in the hinda dutch areas, both those in which there is a gubernemen court or those that establish a religious court as part of the indigenous judiciary or the king's swap court.

- Village courts (dorpsrechts praak) that exist in village communities, which are usually customary courts. ${ }^{16}$

The function of judges in examining and considering cases according to customary law is not limited by law, judges are not bound by provisions regarding evidence. the important thing for judges is to pay attention to whether the customary law is still alive and is maintained by the indigenous peoples concerned, and whether the customary law is still appropriate to be used as material for consideration, or whether the customary law is no longer in accordance with the general feeling and legal awareness of the community, whether Customary law still has material power, or is it against the objectives of national development. ${ }^{17}$

\section{Closing}

Judges as law enforcers, their main task is to judge with justice that can be accounted for. Regarding the legal culture of the community that still exists, judges are prohibited from asking that every case that occurs in a community order be resolved at the court table. Responding to things like this depends on where in an area that still believes in and prioritizes customary law, where it can be resolved with the existing rules in the community legal culture component. The development of legal awareness should be oriented towards efforts to promote the values of the relevant legal regulations and pay attention to the legal communication factor so that the contents of these legal regulations can be known by the special community as the target of the legal regulations themselves.

${ }^{16}$ Yulia. (2016). Buku Ajar Hukum Adat. Sulawesi: Unimal Press. p. 108.

${ }^{17}$ Shalihah, Fithriatus. (2017). Sosiologi Hukum. Depok: Rajawali Press. p. 68. 
Indonesia is a constitutional state based on Pancasila as the basis for life guidelines. Regarding the legal culture that exists in an Indonesian constitutional system today, it needs to be studied and deepened regarding developments or things that are changing. A judge certainly has the right and courage to be accountable for all actions and decisions that have been passed. However, judges must know whether the decision is fair and acceptable in a society with a cultural background and believes that culture is part of the law that still exists in society.

\section{References}

\section{Journal:}

[1] Annisa, Nur Fitra. (2017). Peranan Hakim Sebagai Penegak Hukum Berdasarkan Undang-Undang Nomor 48 Tahun 2009 Tentang Kekuasaan Kehakiman, Jurnal Lex Et Societatis Volume. 5 No. 3.

[2] Fitriciadi, Aidul. (2005). Kekuasaan Kehakiman Yang Merdeka Dan BertanggungJawab di Mahkamah Konstitusi: Upaya Menemukan Keseimbangan. Surakarta: Jurnal Jurisprudence Volume 2 No. 1.

[3] Simamora, Janpatar. (2014). Tafsir Makna Negara Hukum Dalam Perspektif Undang-Undang Dasar Negara Republik Indonesia Tahun 1945. Medan: Jurnal Dinamika Hukum Volume 14 No. 3.

[4] Widayati. (2020). Implementasi Asas Hukum Dalam Pembentukan Peraturan Perundang-Undangan Yang Partisipatif Dan Berkeadilan. Semarang: Jurnal Hukum Volume 36 No.2 Unissula.

\section{Books:}

[1] Mardani. (2017). Etika dan Profesi Hukum. Depok: Rajawali Pers.

[2] Muslih, M. (2013). Negara Hukum Indonesia Dalam Perspektif Teori Hukum Gustav Radbruch (Tiga Nilai Dasar Hukum). Jambi: Legalitas Edisi Volume IV Nomor 1.

[3] Nugroho, Sigit Sapto. (2016). Pengantar Hukum Adat Indonesia. Solo: Pustaka Iltizam.

[4] Safaat, Ali. (2016). Modul Pendidikan Negara Hukum Dan Demokrasi. Jakarta: Pusat Pendidikan Pancasila Dan Konstitusi Mahkamah Konstitusi.

[5] Shalihah, Fithriatus. (2017). Sosiologi Hukum. Depok: Rajawali Press.

[6] Soekanto, Soerjono. (2006). Pengantar Penelitian Hukum. Jakarta: Universitas Indonesia Press.

[7] Usman Rasyid dkk. (2020). Wajah Kekuasaan Kehakiman Indonesia. Yogyakarta: UII Press.

[8] Warassih, Esmi. (2016). Pranata Hukum Sebuah Telaah Sosiologis. Semarang: Pustaka Magister.

[9] Yulia. (2016). Buku Ajar Hukum Adat. Sulawesi: Unimal Press.

[10] Zaidah, Yusna. (2015). Religious Courts in Indonesia. Banjarmasin.

\section{Regulation:}

[1] Act No. 48 of 2009 concerning Judicial Powers. 
ISSN : 2747-2604

Volume 2 Issue 4, December 2020, (591 - 598)

[2] The Constitution of 1945 Republic of Indonesia, the fourth amendment. 